\title{
Ireland in the Musical Imagination of Third Republic France
}

This chapter will examine images of Ireland as evoked in the music of the Third Republic in France with particular focus on the 1924 production of Henri Rabaud's L'Appel de La mer, addressing its libretto, score, and reception history. The musical adaptation of any literary text will always result in some transformation of the original material but when Rabaud (1873-1949) decided to set John Millington Synge's Riders to the Sea as ane-act opera, he strove to retain its authentic local colour, natural dialogue, and references to islander rituals, all the while writing with the Opéra-Comique audience in mind. "They're all gone now, and there isn't anything more the sea can do to me', laments Maurya towards the end of Synge's one-act play about a widow from the Aran Islands who loses her husband and each of her six sons to the surrounding North Atlantic ocean. The isolated island, its people, and traditions comprise Maurya's entire world, one so self-contained and alienated that even the west coast of Ireland seems impossibly distant. How, then, did a 1903 drama about the grinding daily hardship of a tiny fishing village find its way to the cosmopolitan setting of a Parisian opera house in 1924 ?

A most celebrated Franco-Irish literary and musical connection had been established by Hector Berlioz's Neuf mélodies irlandaises (published in 1830 and subsequently retitled Irlande). ${ }^{1}$ Composed nearly a century later, Rabaud's work is one of the most substantial efforts to unite Irish literature and French music, although like many French operas premiered in the 1920 s it faded into obscurity. In contrast, a better-known Riders to 
the Sea (1932), the opera by English composer Ralph Vaughan Williams, successfully broadened the appeal of the work by depoliticising the drama and employing a modernist musical language. ${ }^{2}$ Yet, Parisian critics at the time judged Rabaud's opera as significant. While his music merits more recognition than it currently receives, today the opera is also of major historical interest because it marks a watershed in how French composers portrayed Ireland. Certainly, Rabaud did not entirely dispense with the outdated views of the country projected in earlier works but, courtesy of Synge's text, his depiction of Ireland is grounded in realism. As it appears to be attuned to social and nationalist sensitivities, it thus mirrors wider contemporary French sympathies for Ireland. Given the particular time it emerged, L'Appel de La mer is not just an opera about Ireland but also one embedded in the cultural politics of Third Republic France. Thus it is particularly interesting both to analyse Rabaud's response to early twentieth-century Irish literature, and to consider how L'Appel de la mer engaged with some key aesthetic principles that influenced the operatic repertoire of Third Republic France, namely exoticism and symbolism, and resistance to modernism.

Images of Celtic Ireland in the Music of Third Republic France

In the intervening century between Berlioz's Moore song settings and L'Appel de la mer, a handful of other Irish-themed works were published and performed by composers living in France. Unlike the Berlioz and Rabaud works which were at least rooted in tangible manifestations of

2 Yumiko Kataoka argues the political point, while Byron Adams illustrates that octatonicism was central to Vaughan Williams's Riders. See Yumiko Kataoka, 'Riders to the Sea: Irish Voices, British Echoes', Journal of Irish Studies I8 (2003), 65-73; and Byron Adams, 'Vaughan Williams's Musical Apprenticeship', in Alain Frogley and Aidan J. Thomson, eds, The Cambridge Companion to Vaughan Williams (Cambridge: Cambridge University Press, 2013), 29-55. 
contemporary Ireland - each was respectively based on a text that had been published twenty to thirty years beforehand - these other compositions conjured up visions of the country without being anchored in any concrete national sources. Still, the multifarious means of constructing Ireland in the French musical imagination, including these sometimes whimsical offerings, provide a glimpse of how the French perceived Ireland. In addition, they grant insights into compositional developments during this era. Apart from Berlioz's Neuf mélodies, all the works discussed here belong to the Third Republic, a period fraught with political upheaval, debates about nationhood, implementation of new laws separating church and state, and social change. Traces of these discourses are refracted through music which is ostensibly about Irish myth, culture, and identity but which also participates in discourses about the function of music in French society in the late nineteenth and early twentieth centuries.

Augusta Holmès ( $1847-1903$ ), born in France to an Irish-born father and a mother of Scottish descent, was a foremost figure in this strand of French music history. She is significant in another respect, as an exceptionally successful female composer during the late nineteenth century. ${ }^{3}$ Amongst her prolific output, the symphonic poem Irlande (1882) remains one of her most popular works. ${ }^{4}$ Its premiere prompted the leading French music journal Le Ménestrel to praise Holmès as 'parmi les compositeurs marquants de l'école moderne' [among the noteworthy composers of the

For more on Holmès, see Gérard Gefen, Augusta Holmès: loutrancière (Paris: Belfond, ${ }_{198}$ ). The question of gender as it pertains to the composer has received much attention. For a detailed discussion of gendered critical reaction to Holmès in $188_{9}$, sec Annegret Fauser, Musical Encounters at the 1889 Paris World's Fair (Rochester: Universicy of Rochester Press, 2005), 103-38.

For more on the music of Irlande, see Mary Pierse, 'Close Connections: Nationalism and Artistic Expression in the Opere of Sydney Owenson/Lady Morgan and Augusta Holmès', in Eamon Maher and Catherine Maignant, eds, Franco-Irish Connections in Space and Time: Peregrinations and Ruminations (Oxford: Peter Lang, 2013). See also Timothy Jones, 'Nineteenth-Century Orchestral and Chamber Music' in Richard Langham Smith and Caroline Potter, eds, French Music Since Berlioz (Aldershot: Ashgate, 2006), 53-90. 
modern school]." Six years later Le Ménestrel reiterated its admiration for this 'ouvre virile, bien conçue' [well-conceived, virile work]. ${ }^{6}$ Not long afterwards, it was programmed at the inaugural Feis Ceoil in Dublin in May 1897 . On the eve of this performance, the Irish Times boasted this country's claim to its creator, the "greatest of woman composers." Probably thinking of Holmès's other 'Irish' pieces such as La Chanson de gars de L'Irlande (189r) and Noël d'Irlande (1896), the newspaper stated: 'some of her songs are, perhaps, known to Dublin people, but this will be the first time that an important work by our distinguished countrywoman has been performed in Dublin." "The evidence indicates that the city's musical fraternity saw Holmès as one of their own. With the Feis Ceoil committee defining an Irish composer as one 'of Irish birth or parentage whether resident in Ireland or not', the performance of Irlande helped accomplish one of the festival's key aims - 'to have orchestral concerts of music by Irish composers." Local musicians were certainly responding to a prevailing cultural nationalism with an Irish mode of musical utterance" which was in tune with Holmès's nationalist ideology and symphonic aesthetic: Michele Esposito and Hamilton Harty each composed an Irish Symphony for Feis Ceoil competitions in subsequent years. ${ }^{10}$

As well as galvanising the Irish artistic cause, Irlande indirectly shaped fin-de-siècle French cultural politics. That work and the composer's ancestry came to define Holmès, so that by r 889 Arthur Pougin wrote: "elle chante

Anon., 'Concerts et soirées', Le Ménestrel (2 April r882) (This translation and all subsequent ones are mine). H. Barbedette, 'Paris et départements', Le Ménestrel (2s November 1888 ). For commentary on how Holmès's education and upbringing enabled her to transeend gender barriers, see Pierse, 'Close Connections'. Anon., 'Feis Ceoil', Trish Times (14 May 1897). This article quotes French critic Adolphe Jullien's praise for Holmès.

8 Anon., 'Feis Ceoil'.

9 Jennifer O'Connor, "The Role of Women in Music in Nineteenth-Century Dublin' (PhD diss., National University of Ireland Maynooth, 2010), 215, 211. Patrick Zuk and Séamas de Barra, 'Composition', in Harry White and Barra Boydell, eds, The Encyclopaedia of Music in Ireland (Dublin: UCD Press, 2013), vol. 1, 226. Esposito's symphony dates from 1902 and Harty's from 1904. 
la liberté, la patrie, la gloire [...] qu'elle songe aux douleurs du pays de ses ancêtres [...] qu'elle glorifie notre chère France, sa terre d'adoption' [she sings of liberty, patriotism, glory [...] whether contemplating the sorrows of her ancestral country [...] or extolling our dear France, her adopted land]. ${ }^{11}$ Pougin saw nationalism as so fundamental to Holmès's aesthetic that the essence of her 1882 symphonic poem would resurface in a uniquely French work. Indeed, Holmès recycled and amplified Irlande's themes of freedom and patriotism when she was commissioned to write the Ode triomphale en $l$ 'bonneur du centenaire de $x>89$ for the 1889 Exposition Universelle. One resonance between Irlande and the $O d e$ is that the former alludes in its prefatory text to the voices of the Irish people - 'ton vieux chant triomphal' [your old triumphant song] - while the latter incorporates a multitude of French voices - soldiers, workers, and so on - in its choral parts. ${ }^{12}$ Parallels between Irlande and the Ode were possible partly because of a shared musical language, in other words, Holmès did not strive for an authentic Irish sound or use folk material in her symphonic poem. Still, she does present stylised echoes of the country. ${ }^{13}$

The next significant reference to Ireland in French art music came in 1903 when the cantata theme for the annual Prix de Rome composition competition was officially announced. The Académie des Beaux-Arts chose a dramatic libretto about Celtic Ireland. ${ }^{14}$ Written by Marguerite Coiffier and Eugène Adenis, the libretto was ostensibly based on the Irish legend of Alyssa, although the source of the tale is unclear and may have been fabricated by these authors. 'The story, set in 'fabled times', features the fairy Alyssa, a young Irish chief called Braizil, and a bard. Like Irlande, it is a

I I

12

(1)

13

14

Arthur Pougin, 'Semaine théâtrale', Le Ménestrel (1s September 1889).

Augusta Holmès, Irlande: Poème symphonique, transcription for piano (Paris: Léon Grus, 1882), front matter. For more on the Ode, see Mark Seto, 'Luigi Cherubini and Augusta Holmès', in Donna M. Di Grazia, ed., Nineteenth-Century Choral Music (New York: Rourledge, 2013), 227; and Pierse, 'Close Connections'.

Pierse notes that Irlande includes some Irish pastiche material and a 'noticeable echo' of one of Moore's melodies. See 'Close Connections', 86, 87.

As Celtic Ireland is the theme of Irlande, this decision might have been influenced by the popularity of Holmès's work. 
patriotic call to arms: Braïzil falls in love with Alyssa but the bard tells him he must lead his people into battle, and eventually he chooses duty over love. That year's winner, Raoul Laparra, composed a piece which alludes to the Irish setting by opening with a six-eight harp motif evoking both folk instrumentation and rhythm. ${ }^{15}$ Apart from that, however, his cantata was a fairly conventional exercise. The text's formulaic drama and characterisation were designed to fit a rigid compositional mould, so references to Ireland could only be token ones. Alyssa's ancient setting, mystical atmosphere, forest and waterside scenes, and passionate themes were all generic mainstays of Prix de Rome cantata libretti. They were also hallmarks of the Wagnerian repertoire that reigned on the fin-de-siècle Paris opera stage. As Celtic mythology had inspired Richard Wagner's landmark Tristan und Isolde, the Alyssa text would invariably encourage contestants to respond in a Germanic musical mode. Maurice Ravel entered the competition that year with a convincing cantata that was steeped in Wagnerism and without reference to Alysssa's alleged Irish roots. ${ }^{16}$

Alyssa prompted Ravel to think of Wagner; similarly, other composers at this time did not equate the Celts solely with Ireland - France had its own Celts in Brittany, who in the early twentieth century, made concerted efforts to strengthen their cultural identity. This pan-European Celticism fascinated the American composer Swan Hennessy (1866-1929) who spent most of his life in Paris. ${ }^{17}$ An obscure figure today, Hennessy mostly wrote amateur-level solo piano and chamber music; in a nod to his Irish heritage, he published numerous 'Celtic' works and a handful of ostensibly 'Irish' scores. ${ }^{18}$ The latter includes the 1908 Variations sur un air irlandais ancien for solo piano. ${ }^{19}$ An unidentified air is subject to twelve short treatments.

Raoul Laparra, Alyssa: légende inlandaise (Paris: Enoch \& Cic, 1903), 1.

Robin Holloway, On Missic: Essays and Diversions (Brinkworth: Claridge Press, 2003 ), 276.

I wish to thank Axel Klein for bringing Hennessy's music to my attention. Hennessy received very little French critical attention. His death notice in $L e A e ́ n e s t r e l$ on 1 November 1929 simply read: 'Ce délicat musician avait écrit un certain nombre de trios, quatuors et de pièces de piano.'

Swan Hennessy, Variations sur un air irlandaise ancien (Schott: Paris, 1908 ). 
The variations mostly maintain the lyrical nature of the monophonic theme: forays into a more opaque impressionist sound-world are rare, with the exception of the tenth variation. Here, the juxtaposition of an Irishtinged melody in the right hand and chromatic chordal sonorities of the modern French school in the left hand has the effect of musically linking the two countries. ${ }^{20}$ Hennessy continued writing in this style in the 1920 , for instance in his Rhapsodie gaélique for cello and piano (1925), but it was becoming dated as French images of Ireland changed. ${ }^{21}$

Of all the post-r870 music mentioned thus far, only Hennessy's Variations purport to evoke Ireland with overt reference to native music. So, for a period of about thirty years Ireland was generally constructed in the musical imagination of 'Third Republic France using a late nineteenthcentury, Romantic idiom. Whether writing for voice, a solo instrument, orchestra, or with a dramatic setting in mind, composers used the standard forms and techniques of European art music to convey a loose sense of Irish myth and nationalist ideology. This is true of Holmès's output in the r88os (Irlande) and 1890 (La Chanson de gars de I'Irlande and Noël d'Irlande), of the Laparra and Ravel cantatas in 1903, and of the small-scale piano pieces Hennessy produced in the first two decades of the twentieth century. None of these compositions managed to convey the 'authentic' folk reality of Ireland. With the advent of the Irish Literary Revival in the late I 890 os, however, the country and its leading creative figures were afforded greater recognition in the cultural life of the French capital. Subsequent to this shift, composers such as Rabaud, who wished to express some aspect of Irish identity, could no longer offer up the musical equivalent of outdated tropes stemming from mythologised folk memories. Instead, with a new Irish literary movement gathering pace, major figures in French music needed to engage in a more profound way with the country.

20 This judgement is based on the musical material presented in Hennessy's Variations, 8-9.

21 The absence of Parisian press commentary on any of Hennessy's music suggests that neither in general, nor in the specific evocations of Ireland, was it considered to be of major interest or novelty. 


\section{French Perceptions of the Celtic Revival}

The Irish Literary Revival was rooted in the nineteenth-century Celtic Revival which, especially after the founding of the Gaelic League in 1893 , attempted to renew interest in the national language and promote interest in native folklore, music, and heritage. The subsequent establishment of the Irish Literary Theatre in 1899 by Lady Gregory, William Butler Yeats and Edward Martyn incubated a new nationalist movement in drama pioneered by figureheads such as Synge, who 'emphasised that his plays were drawn from observations of a specifically Irish reality. ${ }^{22}$ Riders to the Sea was written in 1903 and premiered in Molesworth Hall, Dublin on 25 February 1904. It was another decade before France properly discovered the work of Synge but, in the intervening years, Irish revivalist politics were making waves in Paris. Le Figaro advertised a public talk on "The Irish Revival in the Nineteenth Century' in 1906, while in 1912 L'Intransigeant reported on Home Rule with a striking trilingual headline: "Eiré [sic]" et "Sassanach": L'Irlande celtique et le Home Rule" it announced on the front page. ${ }^{23}$ Despite this article's ostensible concern with political manoeuvring, much of it is mired in misty-eyed sentimentality about a people who "trop longtemps on a pleuré les malheurs de la Shean Vhan ' hocht' [for too long have wept about the misfortunes of the Shean Vhan Vhocht (sic) ]. ${ }^{24}$ All was set to change, Jean Malye wrote: ‘Aujourd'hui 700,000 personnes parlent celtique [...] l'effort celtique se manifeste partout' ['Today 700,000 people speak Gaelic [...] the Celtic effort is manifest everywhere]. ${ }^{25}$ Concluding with an allusion to the ending of the 1920 play by Lady Gregory and Yeats, he proclaimed: 'L'Irlande celtique ne veut pas du Home Rule anglais: son

\footnotetext{
22 Oona Frawley, "The Shadows of the Glen and Riders to the Sea", in P.J. Mathews, ed., The Cambridge Companion to J.M. Synge (Cambridge: Cambridge University Press, 2010), 16.

23 Jean Malye, "Eiré" et “Sassanach": L'Irlande celtique et Ie Home Rule', L'Intransigeant (29 April 1912).

24 Malye, "Eiré" et "Sassanach": L'Irlande eeltique et le Home Rule'.

25 Malye, "Eiré" et "Sassanach": L'Irlande celtique et le Home Rulc".
} 
indépendance véritable datera du jour où le Catbleen ni Hoolihan, jeune et libre, saluera le monde' [Celtic Ireland does not want English Home Rule; her independence will date from the day when Catbleen Ni Hooliban [sic], young and free, greets the world]. ${ }^{26}$

L'Intransigeant's stance typified how the French press regarded Ireland at this time, although Malye seems to have been particularly familiar with the political symbolism attached to cultural tropes such as the Sean bhean bhocht and Kathleen Ni Houlihan. Perhaps he was subtly reminding readers of France's historical investment in the Irish cause, for the 'Sean bhean bhocht' song which dates from shortly after 1798 starts by celebrating French participation in the Rebellion:

"The French are on the sea,' says the Sean Bhean Bhocht,

'Oh, the French are in the bay, they'll be here without delay,

And the Orange will decay, says the Sean Bhean Bhocht.

This episode of Irish history, as narrated in the Sean Bhean Bhocht, was in turn dramatised in Catbleen $N i$ Houliban. Yet despite these allusions to a shared Irish and French past, L'Intransigeant's account of a resurgent nation is prone to exoticising tendencies. A fascination with 'la vieille langue des Gaels' [the ancient language of the Gaels] is apparent: 'Gan teanga gantir [sic] (pas de langue, pas de pays) disent-ils' [No language, no country, they say $].{ }^{27}$ Later, the journalist tries to capture Ireland in a broader sense:

Limerick, qui se rappelle toujours la violation du traité de r691, Galway, ancienne reine des mers [...] les montagnes bleues de Connemara [...] Glendalough et son lac fatal murmure toujours son histoire d'amour, Killarney enchante toujours par son charme.

[Limerick, a place which still recalls the violation of the 1691 Treaty of Limerick; Galway, formerly queen of the seas [...] the steel-blue mountains of Connemara [...] Glendalough and her facal lake still whisper of a legendary romance, Killarney's charm is still enchanting. $]^{28}$

26 Malye, "Eiré" et "Sassanach".

27 Ibid.

28 Tbid. 
The abundant references to a unique language, people, geography, history and mythology paint the country as Other. Importantly, Malye wrote this piece at a time when Paris was in the throes of a theatrical obsession with exoticism. Ever since they had arrived in the French capital in 1909, the musico-choreographic presentations by the Ballets Russes of exotic tales from Russia, the Far East and elsewhere had been wildly popular with the French public.

In this environment, one could see the potential in Riders to the Sea as an exotic opera. French composers for the stage had long been inspired by a range of remote settings: Georges Bizet's Carmen (1875) was set in Spain, Reynaldo Hahn's L'Île du rêve (1893) in Polynesia, and Florent Schmitt's Tragédie de Salomé (1907) in Egypt. Thus, an opera on an Irish theme could have added to a pre-existing repertoire. Rabaud, though, would plough a different route. Why? Perhaps because Synge's artistic world was entwined with that of the current Parisian cultural scene. He, more than other Irish playwrights, is likely to have intrigued French composers for a host of reasons: his previous music career, the contemporary French influence on his writing, and reports of the riots which had greeted the Dublin premiere of his Playboy of the Western World (1907). ${ }^{29}$ That play reached the Parisian stage in December 1913, just six months after Igor Stravinsky's ballet The Rite of Spring had scandalised theatregoers and sparked disturbances at the Théâtre des Champs-Élysées. Both works provoked outrage for perceived vulgarity of content and style. By the eve of World War I then, modern Ireland occupied a more prominent position in French cultural thought than was the case in the late nineteenth century when Holmès and her peers had paid homage to ancient Ireland.

At least one music critic made a point of detailing Synge's past: 'il avait travaillé le violin, le piano et obtenu au Conservatoire de son pays, dès l'âge de vingt ans, les prix d'harmonie et de contrepoint. Il s'en fut ensuite compléter en Allemagne son éducation musicale:" [He had studied violin, piano, and won prizes in harmony and counterpoint from the conservatory in his own country by the age of twenty. He then went to Germany to complete his musical education.] Anon.. 'Avant-première: à l'Opéra-Comique L'Appel de La mer de M. Henri Rabaud', Le Ménestrel (4 April 1924 ). 


\section{Setting the Scene for LiAppel de la mer}

The outbreak of war profoundly altered the Parisian music scene and its effects were still felt in the rgzos when L'Appel de la mer appeared on the opera stage. The two flagship institutions, the Paris Opéra and the Opéra-Comique, had adapted to the conflict by concentrating their limited resources on patriotic pageants rather than on complex new works. Few premieres were given by either company during 1914-18; instead, they were delayed until the rg20s. As a consequence, the predominantly tonal pre-war compositional language of these 'postponed' operas immediately seemed dated when compared to avant-garde developments in other genres, such as ballet, which had actually gained momentum during the war. Following Stravinsky's abrasive modernism, Erik Satie further startled audiences with gunshot sound effects and American ragtime in Parade (I9I7). Shortly afterwards Darius Milhaud built on these experiments with a polytonal tribute to Harlem jazz as part of La Création du monde (1923). The Milhaud ballet premiered the year before L'Appel de la mer but the two had little in common. 'Modernism is the enemy' was Rabaud's slogan, a reactionary public stance which partly explains why LAppel de la mer failed to excite audiences, vanished from the repertoire, and remains neglected by musicologists today. ${ }^{30}$

In early 1924 , however, an air of anticipation surrounded L'Appel de la mer, as Rabaud had previously scored a hit at the Opéra-Comique in May I9I4 with an exotic Egyptian spectacle called Mârouf, savetier du Caire. Mârouf was cited by André Coeuroy in 1922 as a work which featured "toutes les hardiesses de l'école moderne' [all the boldness of the modern school], despite the composer's disinclination to align his art with a particular aesthetic. ${ }^{31}$ During the post-war period, Rabaud's conservative reputation <http://oxfordmusiconline.com> accessed 10 May 2014. 
was no barrier to interest in his work. As a reporter for Le Ménestrel wrote on the eve of the 1924 première: 'le succès universel et persistant de $M a r o u f$ donneront à la première représentation de L'Appel de la mer une importance que-si nous en croyons les échos de l'Opéra-Comique - la beauté de l'ouuvre ne démentira pas' [Mârouf's universal and enduring success makes L'Appel de la mer's first performance an important occasion which - if the rumours from the Opéra-Comique are true - the beauty of this work measures up to]. ${ }^{32}$ Rabaud was the subject of close scrutiny for another reason: in 1922 he had been appointed the director of the Paris Conservatoire, the country's government-funded centre of music education. With a history of training singers, instrumentalists, and composers for careers at the capital's two major opera companies, an Opéra-Comique première courtesy of a reigning Conservatoire director was always an auspicious event. Such events assumed an even greater official importance in the 1920 s as opera became ensnared in post-war political debates concerning the nature of French identity. Key productions in this vein included: Vincent d'Indy's Légende de Saint-Christophe (1920), a paean to Christian martyrdom that fused religious belief with right-wing nationalism; Marcel Bertrand's Sainte Odile (1923), which alluded to the country's reclaiming of Alsace-Lorraine in 1918; and Joseph Canteloube's Le Mas (1929), which championed regionalist ideology. By turn, L'Appel de La mer is memorable for how Maurya (in diametric opposition to the d'Indy, Bertrand, and Canteloube protagonists) loses faith in doctrinaire Catholicism and instead seeks solace in keening rituals and pagan festivals. The subtlety of Synge's rhetoric was lost on the critics, however. In any case, Rabaud's $M a$ arouf had them primed not for a sermon but for another exotic opera. So what did the composer deliver?

Rabaud decided to set Riders to the Sea as an opera after reading the play during a trip to Boston in $1919 .{ }^{33}$ Deciding against using an available translation, he produced his own libretto: "version presque littérale, qui,

Anon., 'Avant-première: à l'Opéra-Comique'.

33 As reported in Le Ménestrel, (4 April 1924). A performance of Riders to tbe Sea at the Petit-Théâtre anglais, Paris, was advertised in Le Figano on 9 March 1915. Whether Rabaud attended this is or not is unknown. 
tout en conservant au dialogue - les personnages sont d'humbles gens de mer - [...] corrige seulement quelques tournures trop populaires pour se prêter à l'expression musicale' [an almost literal version, which, keeping the sense of the informal dialogue - the characters are humble, seafaring people - [...] corrects only the occasional colloquial turn of phrase in order to enhance the musical expression]. ${ }^{34}$ In trying to preserve the authenticity of Synge's Aran-Islands dialect, Rabaud, contrary to expectations, signalled that L'Appel de La mer would be shaped more by realism than exoticism. His study of Synge's text would have revealed a further reason to avoid reductive exoticism: such an approach would have been incompatible with Riders to the Sea's stylistic and thematic resemblances to French turn-of-the-century aesthetic movements. These similarities were the result of Synge's first-hand, sustained absorption in the country's literary and linguistic cultures. ${ }^{35}$ One Parisian music critic detailed how Synge spent $1895-98$ in France, "fréquentant nos bibliothèques, suivant les cours du Collège de France et de la Sorbonne, se familiarisant avec nos classiques et étudiant d'autre part ... la langue bretonne' [frequenting our libraries, attending classes at the Collège de France and the Sorbonne, familiarising himself with our classics ... and also studying the Breton language]. ${ }^{36}$

Synge developed a deep affinity for Maurice Maeterlinck's symbolist plays, which can be perceived in Riders to the Sea; for instance, the drowning of the sons echoes the plot of Maeterlinck's Intérieur (1894). ${ }^{37}$ In Synge's drama, Maurya lives with her daughters Cathleen and Nora and son Bartley. Her father-in-law, husband, and five other sons have already been lost to the sea, the most recent victim being Michael, whose body has just washed up in Donegal. Against his mother's wishes, Bartley then departs for Galway. Maurya predicts she will have no sons left and, as prophesied, Bartley's drowned body is returned to the family towards

Anon., 'Avant-première: à l'Opéra-Comique', Le Ménestrel. Harry White, Music and the Irish Literary Imagination (Oxford: Oxford University Press, 2008 ), 117 .

36 Anon., 'Avant-première: à l'Opéra-Comique', Le Ménestrel. 
the end of the play. Beyond reminiscences of specific Maeterlinck plays, Synge's text reproduces a few of Maeterlinck's general stylistic qualities: the nature symbolism, claustrophobic atmosphere, characters' isolation from the outside world, and fatalistic narrative are all familiar from both Pelléas et Mélisande (1893) and Ariane et Barbe-Bleue (1901). Those plays had also been adapted as operas, by Debussy and Paul Dukas respectively, and staged by the Opéra-Comique in 1902 and 1907.

\section{Musical Aspects of L'Appel de la mer}

Traces of the early twentieth-century modernism of Dukas and Debussy linger in Rabaud's post-war opera score, suggesting that Maeterlinck and Synge prompted similar responses in French composers of this period. As one would thus expect, L'Appel de la mer does not quite embrace Milhaud's cutting-edge polytonality but the tonal language extends to incorporate the modal structures of Irish traditional music. The music is anchored in the $G$ mixolydian mode, a mode which differs from the major scale by flattening the seventh scale degree. Rabaud, however, altered the mixolydian mode to include a raised fourth scale degree, thereby generating tritonal dissonance that mirrors the unsettling mood of the libretto. At distinct moments (for instance: the first iteration in bar 4, its appearance as the curtain rises in bar I5, and in the last bar), the harmony is voiced as an A major chord stacked over a $\mathrm{G}$ dominant seventh such that this modal idiom generates a modern sound. ${ }^{38}$ The modal colour introduced in the orchestral prelude is later inflected by more particular references to native Irish music.

As the opera first unfolds, however, it is indebted to Pelléas. Like Debussy, Rabaud uses the orchestra to establish the mood - its turbulence here evokes the sea - and, adhering to his predecessor's style, the 
vocal writing is often declamatory. As in Pelléas, Rabaud's characters tend to communicate with each other in a prosaic, syllabic fashion unless the mood of the text calls for a more affective musical response. The action begins with Nora and Cathleen discussing whether clothes found on a Donegal shore could belong to their brother Michael. They sing quietly in a recitative style that ebbs and flows with the natural spoken rhythms of the libretto. Maurya enters the conversation with a more lilting, sentimental part as she mentions Bartley's plan to travel to Connemara. Although she insists: 'il n'ira pas aujourd'hui' [he will not go today], Bartley's relentless, galloping orchestral theme asserts otherwise and he soon sets off. ${ }^{39}$ Maurya laments his departure with a melismatic outpouring of emotion reminiscent of sean-nós singing, but whereas the sean-nós singer would perform unaccompanied and in the Irish language, this passage is in French and the orchestra maintains a quiet presence. ${ }^{40}$ Rabaud's approach to the use of folk material echoes that of Debussy and Dukas, both of whom featured French folk songs in their respective operas but only as climactic set-pieces. ${ }^{41}$ The understated vocal expression in much of L'Appel de la mer amplifies the realism inherent in Synge's text, while the wisely-judged incorporation of native tunes and techniques ensures that the opera never descends into stage-Irish farce.

When the score has recourse to Irish music, it embraces it imaginatively. Nora tells Cathleen what the priest had to say about their latest tragedy: "Si c'est à Michael," dit-il, "vous pouvez dire à votre mère qu'il est en terre chrétienne, par la grâce de Dieu" ['If [the clothes] are Michael's,' he says, 'you can tell your mother that he is in Christian ground now by the grace of God']. Nora mimics his words to the tune of 'The Wearing of the Green'.42

See Henri Rabaud, I'Appel de la mer, vocal score (Paris: Max Eschig \& Cie, 1923), II, 13.

Ibid., $28-9$.

In Pelléas, Mélisande sings 'Mes longs cheveux' from her tower in Act III. In Ariane, Bluebeard's imprisoned wives sing 'Les cinq filles d'Orlamonde' towards the end of Act I.

Rabaud, L'Appel de la mer, s. 
The spirited, sentimental melody captures the young priest's naivety and lack of authority. Maurya later dismisses him because 'ces hommes là n'y connaissent rien, à la mer' [it's little the likes of him know of the sea]. ${ }^{43}$ In contrast, Maurya is established as a sincere, serious figure by singing in an Irish folk style with far greater sensitivity. The best example is found towards the end of the opera. Over a drone accompaniment typical of the traditional genre, she mourns the men in her family, her voice wandering plaintively around the true $G$ mixolydian mode. ${ }^{4+}$ Remembering how other islanders brought news of a drowning when Bartley was a baby, she recounts this to the tune of "She Moved through the Fair." Als Als in the $G$ mixolydian mode, it is an apt melodic choice for this scene. The last main allusion to Irish tradition arrives towards the end of the opera when Bartley's body is brought home. Women keen over his body, a ritual which Rabaud reproduces as a soft, almost inaudible hum initially on the pitches $\mathrm{D}$ and $\mathrm{E}$, but soon expanded into a fuller lament in $\mathrm{E}$ minor. ${ }^{46}$ Realism is the order of the day as the music seeks to convey the private, emotional truth of the characters.

\section{Ibid., 65.}

44 Ibid., 67 onwards. This is the 'true' mixolydian mode in the sense that Rabaud does not raise the fourth scale degree here, as he had previously done.

45 Ibid., 70, to the words: 'J'étais assise ici; Bartley, encore un bébé, était couché sur mes deux genoux; er j'ai vu deux femmes, puis trois femmes, puis quatre femmes, entrer et se signer sans dire un mot.' [I was sitting here; Bartley, still a baby, was asleep on my knees; and I saw two, then three, then four, women enter and make the sign of the cross without saying a word.]

46 Women's voices are heard first from the corridor and are then followed by the keening, 71;75ff. 


\section{French Reaction to L'Appel de la mer}

Starring Suzanne Balguerie as Maurya, the opera officially premiered on Io April 1924 but most critics attended the dress rehearsal on the afternoon of Saturday 5 April. ${ }^{47}$ Several positive commentaries appeared in the press over the next week, most of these focusing on realism, the use of Irish music, symbolism, and Gallic influences on the libretto. Despite Rabaud's track record with Marouf, L'APpel de la mer could not be categorised as exotic: it lacked the seductive female Other and the supernatural element integral to the earlier work. Instead of offering escapist fantasy, the 1924 opera is grounded in Synge's unvarnished realism. From the very first notes, it made a visceral impact - as Paul Bertrand stated in Le Ménestrel: 'c'est la musique qui, dès le début du prélude, évoque, en de larges accords dissonants, la mer tourmentée' [from the start of the prelude, the music's thick dissonant chords evoke the tormented sea]. ${ }^{48}$ André Messager of $L e$ Figaro reacted likewise: "le bruit de la mer se fait entendre tout au long de l'ouvrage par grandes poussées sonores qui donnent l'impression des coups de bélier de ses flots sur les roches' [the noise of the sea makes itself heard throughout the work through great sonic gestures that give the impression of water hammers as the waves hit the rocks]. ${ }^{49}$ The sonorous symbolism derives from the construct of the sea as antagonist, a device which reviewers recognised from Intérieur, as well as from novels such as Pierre Loti's Pécheur d'Islande (1886) and Victor Hugo's Travailleurs de La mer (1866). ${ }^{50}$ Apart from making intertextual allusions to French literature,

One source names Thursday ro April 1924 as the official date: see Nicole Wild and David Charlton, Théatre de l'Opéra-Comique Paris: Répertoire $1762-1972$ (Belgium: Mardaga, 2005), 142. Le Figaro on S April 1924 advertised the dress rehearsal caking place that afternoon. Paul Bertrand, 'La Semaine musicale', Le Ménestrel (i1 April 1924). André Messager, 'Les Premières', Le Figaro (7 April 1924).

At least two critics remarked on this: Adolphe Boschot, 'La Vie musicale', L'Écho de Paris (9 April 1924); and Louis Schneider, 'Le Gauloiss au théâtre', Le Gaulois (7 April 1924). 
the composer demonstrated a keen sensitivity towards Synge's play too. As Messager observed: 'M. Rabaud [...] s'est appliqué à commenter et renforcer le pathétique de situations extrêmement dramatiques par elles-mêmes’ [Mr Rabaud has applied himself to commenting on and reinforcing the pathos of situations that are extremely dramatic in and of themselves]. ${ }^{51}$ Louis Schneider in Le Gaulois similarly applauded the composer for writing an opera where 'la musique est à sa place sans ralentir l'action' [music is in the right place without slowing down the action]. ${ }^{52}$ Stylistic fidelity to Synge's drama was integral to the overall production. As Adolphe Jullien observed: 'la mise en scène, très exacte en son réalisme, ajoute encore à l'intensité d'un spectacle infiniment triste' [the staging, which is very exact in its realism, further adds to the intensity of this infinitely sad spectacle.] ${ }^{53}$

Where L'Appel de la mer really intrigued Parisians was in its appropriation of Irish culture. Commentators such as Adolphe Boschot regarded the work as authentic due to Synge's first-hand experience of the Aran Islands and its people. Paraphrasing Synge, Boschot observed that: 'ces âmes frustes [...] savaient vivre et mourir' [these frustrated souls [...] knew how to live and die]. ${ }^{54}$ In so saying, he highlighted the fatalistic world-view of the islands' inhabitants, which the play reproduced. To the satisfaction of critics such as Henry Malherbe, Rabaud's opera remained true to these folk origins. Malherbe had a good ear for native inflections in the score: 'J'ai cru discerner quelques souvenirs de deux ou trois mélodies irlandaises de Moore' [I thought I discerned a few memories of two or three Moore's melodies]." He further identified 'The Wearing of the Green' and 'Ies plaints funèbres traditionnelles d'Erin, le ritual Caoin ou Keen ou Keening, que Lady Gregory a consigné' [the traditional funeral cries from Erin, the ritual Caoin or Keen or Keening to which Lady Gregory referred]. ${ }^{56}$

SI Messager, 'Les Premières'.

52 Schneider, "Le Gaulois au théâtre".

53 Adolphe Jullien, 'Revue musicale', Joumal des débats poliziques et listéraires (13 April 1924 ).

54 Boschot, 'La Vic musicale'.

55 Henry Malherbe, Chronique musicale', Le Temps (9 April 1924).

56 Ibid. 
These reviews show French music critics of the 1920s to be wellinformed about Ireland's indigenous vocal traditions and attendant social customs. Unlike the central European symphonism of Holmès's Irlande, or the Alyssa cantata texts of dubious provenance, or Hennessy's vaguely Celtic salon music, L'Appel de la mer represented a real Irish community with the score giving full voice to its folk traditions. Staging such a work at the Opéra-Comique could only have happened during the historical moment of the 19zos when there was acute French awareness of Ireland's plight. The signing of the Anglo-Irish Treaty in December $192 x$ had prompted $L e$ Figaro to run two front-page articles on the matter. One of these queried "République" ou "État libre"?' [ Republic' or "Free State?'] in reference to continuing political difficulties, It concluded by quoting Seán T. O’Kelly: "La France nous a toujours manifesté sa sympathie, et j'espère qu'un jour la "République irlandaise" pourra lui témoigner sa reconnaissance" [France has always been sympathetic to us and I hope that one day the 'Irish Republic' will be able to show its gratitude]. ${ }^{57}$

Produced at a time when Ireland was attempting to assert its political independence, L'Appel de la mer is an invaluable artistic artefact and historical document. Rabaud's nuanced treatment of Synge's drama forms a nexus of creative connections between early twentieth-century Irish literature and French music. Moreover, the opera functions as a focal point for understanding how cultural thought about Ireland evolved in Third Republic France, reflecting the gradual transformation from a paternalistic view of an oppressed nation to a more modern acceptance and recognition of Ireland's emerging statehood. 
